\title{
Negotiating identities in the context of social work goals: \\ the case of an intercultural institutional interaction ${ }^{1}$
}

\section{Dorien Van De Mieroop \& Marleen van der Haar}

\begin{abstract}
We discuss the implications of identities constructed by an Afghan client in a conversation with her Dutch social worker. In this institutional interaction the professional's dominant position is both underlined and mitigated and there is room for topic initiation by the client as well. We singled out two crucial client identities that appear to produce diverging interpretations: (1) the fearful woman and (2) the shameful woman. The former is discussed at great length and is linked to the institutional agenda. The latter, however, does not seem to comply with the empowerment discourse currently present in Dutch social work. In spite of the social worker's attempts to reframe this identity, the client persists and relates her feelings of shame to her cultural background, which functions as an explanatory factor in the interaction. The enacted roles of both participants lay bare the social work tension of intervening in people's lives while taking into account the client's perspective and social work goals. Furthermore, this interaction is a good illustration of the way a migrant's identities are performed and negotiated in an encounter with a so-called 'other'.
\end{abstract}

\section{Identities in the post-modern society}

In this article we explore the way identities are constructed in an institutional interaction in the context of the enactment of social roles related to the institutional setting. Identities are

\footnotetext{
${ }^{1}$ An earlier version of this paper was presented at the IGALA 4 Conference (2006).
} 
'extremely complex construct[s]' (De Fina, 2003, p.15). We take a constructivist perspective and follow Hall, Sarangi and Slembrouck (1999, p.293) who argue that 'role and identity are not regarded as fixed categories but as resources which actors draw on to carry out everyday lives'. So, 'directly contrary to what appears to be its settled semantic career, this concept of identity does not signal that stable core of the self' (Hall, 2000, p.17). This constructivist view on identity is 'by now a truism within discourse studies' (Androutsopoulos \& Georgakopoulou, 2003, p.1).

Current post-modern societies characterized by 'social processes as globalization and massive migrations' (De Fina, 2006, p.351) have increased 'contact with 'the other' [which] has brought with it a problematization of the concept of identity itself and an effort to understand the relationship between people's sense of membership in a community, the beliefs and social practices that define that sense of membership, and its expression and manifestation in social behavior' (De Fina, 2006, p. 351). Since this situation further challenges and unsettles our senses of self (Baynham, 2006) and invites us to look at identity 'from a relational perspective as involving as much what we are not as what we are' (Baynham, 2006, p. 394-395), it is crucial to take on a perspective that focuses on the way identities are being performed in particular conversations. Also Blommaert (2005) emphasizes to take such a performance-approach to identities and to see how in practice categories are enacted and identities are constructed. Blommaert argues that identities are semiotic constructs which can be set in a framework of 'polycentric and stratified systems in which hierarchies in identities can be developed' and that this stratification of identities and semiotic resources depend on its environment (2005, p.211). We follow Blommaert's argument that the performing of identity involves 'the mobilisation of a whole repertoire of identity features converted into complex and subtle moment-to-moment speaking positions' (2005, p.232).

This paper investigates the way identity is negotiated within a specific social work session between a female social worker with a Dutch background, and a female client with an Afghan background from a performance-approach. We approach this encounter also as a an intercultural communication, but following Verschueren (2008, p.22) we emphasize that as analysts we "distance ourselves from any essentialist substantiation of the notion of "culture". This means that 
we perceive culture as a dynamic and ever-in-motion social construction that "only exists in the act of being performed" (Baumann, 1999, p.26). Furthermore, we consider the session as a 'communicative practice' embedded in the 'professional tradition' of social work (Bulcaen \& Blommaert, 1997). That is, we explain the professional-client interaction looking into the enactment of a social work discourse from a discourse analytical perspective. We will focus specifically on the way in which identities are negotiated, in relation to the different roles that are being enacted and how both change in relation to the topics that are being discussed in this institutional setting. In the conclusion, we will discuss all these elements and relate them to the views on identity that were discussed above.

\section{Social work in the Netherlands}

Social work is about the management of everyday lives of individuals (Gastelaars \& van der Haar, 2007). In the Netherlands, this free-of-charge assistance provided to people with both material and psychosocial problems is strongly related to social policy. Being a product of the welfare state, social work is a political-normative project framing the practices of professionals in the social sector (De Boer \& Duyvendak, 2004). The current government administration defines three aims: increasing the self-realisation of people, stimulating their self-reliance, and stimulating their participation in society (Dutch Welfare Law, 1994, Art. 1.b1). In this respect, Struijs and Brinkman (1996) pointed at the dominant 'social morality' in The Netherlands, at the liberal morality of individual freedom in particular, and its influence on the hegemonic discourse in the social sector. That is, this liberal morality is reflected in the social sector insofar as the latter stresses the importance of independence, self-reliance and empowerment of its clients (Struijs \& Brinkman, 1996).

Dutch social workers aspire to be 'easily accessible' for their clients and to tone down hierarchy in the relationship. The social workers in this ethnographic study characterize their professional attitude as 'client-centred' and say that in practicing social work they 'link up where the client stands'. 
Stenson (1993) argues that the social workers' role of extending citizenship to clients encourages the egalitarian friendship model of social worker-client relations which results in the operation of two simultaneous modes of conversational practices: a citizen exchange discourse (talk as if among equals) and hierarchical, normalizing discourse, in which the client is encouraged to adopt the subject position of storyteller ('thus offering personal information for scrutiny', Stenson, 1993, p.53) and the agenda of the social worker drives the conversation.

Furthermore, on the basis of their study on migrant women shelters in Belgium which includes observations of interactions between professionals and clients Bulcaen and Blommaert indicate that social workers have 'a large reflexive consciousness about their professional practice' (1999, p.140) and appear to seriously consider their dominant position as professionals regarding 'talking, decision making and interpreting' (1999, p.140). According to Bulcaen and Blommaert (1999, p.140) these social workers struggle to avoid stereotypes in their professional practice, as for example the image of an 'underprivileged, poorly educated and isolated woman'. Yet in the case of migrants, Bulcaen and Blommaert show that the same social workers do make use of so-called black-and-white schemata that even pre-structure the actual social assistance. Moreover, they argue that despite the fact that 'the words of the client provide sufficient space to situate it in a different more balanced story', the black-and-white schemata that interpret the client's situation as 'a classical case' do dominate (1999, p.141). In other words, the social workers often construct a certain stereotypical identity for their clients and interpret their talk from this perspective.

\section{Research questions}

Our research questions are: 1) How do the two actors establish their social roles of social worker and client in a social work session and, 2) how are identities constructed in this interaction?

We frame the first question in terms of the way power is expressed. As Wang (2006) argues, a power-free interaction is an unattainable ideal. We assume that particularly in institutional interaction, power plays a role, if only because of the professional's control of topic 
development which is almost inherent to a goal-oriented conversation. With regard to the second question, we focus particularly on the social positionings of the client and the social worker's responses and co-constructions of them. We single out two dominant identity constructions because of their implications for the way social work is enacted in this conversation and we relate these identity constructions to the central topics of this conversation. Finally, we draw theoretical conclusions on the implications of these identity constructions.

To answer these research questions, we focus on linguistic markers of identity construction. As De Fina (2003) observes, these markers can be situated on three levels, namely the lexical, the textual pragmatic and the interactional level. We illustrate these with examples from our own analyses:

(1) the lexical level: e.g. the lexical mirroring in fragment 4 as a signal of the social worker's effort to link up with the client;

(2) the textual pragmatic level: e.g. the argumentation as proposed by the social worker in fragment 4 which signals her proposal of an alternative identity construction;

(3) the interactional level: e.g. the social worker's use of affirmative responses in fragment 1, as opposed to her usage of continuers in fragment 3 , indicate different stances towards the client's positions in these respective fragments.

Following De Fina, we propose to integrate all these levels in the analysis so that we get a holistic view of the identity constructions in this institutional dialogue. This type of analysis 'reveals how narrators' local displays of identity relate to more global conceptualizations about the self and its membership into groups' (De Fina, 2006, p.374).

\section{Data}

The data presented here are part of a 3-month ethnographic study of a social service organisation in a mid-sized city in the Netherlands in 2003 that focused on the way social workers relate to their culturally diverse clientele. ${ }^{2} \mathrm{~A}$ year later, the corpus was enriched with some additional interviews and observations. The corpus consists of 26 professional-client interactions

\footnotetext{
${ }^{2}$ The data were collected by Marleen van der Haar.
} 
with clients of both migrant and native backgrounds. The data also include audio-recorded semistructured in-depth interviews with 15 social workers on their professional vision and work practices in general and, more specifically, as those relate to cultural diversity. The social workers selected which cases were to be observed and asked the client for permission to have an observer present for one session. The researcher selected the interviewees.

The data for this paper consist of a half-an-hour session between a 33-year-old female social worker with a Dutch background and a 22-year-old female client with an Afghan background. The session has the form of a semi-structured interview and takes place in a counselling room in the social service organisation under study. The language spoken during the session is Dutch. The session was audio-taped by the researcher and later transcribed, including observational notes about nonverbal actions. Data from an interview with the social worker are also part of the analysis. We selected this session for our analysis because the interactants explicitly and elaborately discuss the topic of culture, also at the initiative of the client, which is fairly uncommon in the corpus. With regard to the social worker's role as a professional performing social work discourse, this session is similar to other cases within the corpus.

\section{Case description}

The client has been in the Netherlands for three years. According to the social worker, the client migrated because of an arranged marriage to an Afghan Dutch man, to whom she was promised at the age of fourteen. During her marriage she was abused and isolated by her husband and after a while she decided to flee to a women's shelter. Both the family of the woman and the family of the man, including the husband himself, disapprove of her decision. Moreover, the woman, who is living alone after her stay in the women's shelter, tells the social worker that she is very much afraid that her husband will find out where she lives and will come to hurt her. At the moment, the client has decided not to have contact with her family in Afghanistan because, as the social worker explains, 'it distresses her deeply'. At the time of the encounter we will discuss here, the woman is not officially divorced and has no certainty about her permit to stay in the Netherlands, although she does take Dutch language classes. The female social worker has 
been in contact with the client for some months now. They have regular contact; this is their fifth face-to-face meeting. According to the social worker she intends to broaden the client's social network and to help her start an independent existence. The social worker stresses that she mostly works on practical matters. She explains to the researcher: 'I do not go into the past too much and I do not do that because uh it is all very uncertain in the here and now [...] unless she very much talks about it herself, but then I also often keep it a bit short'. In the analyses we will see how this approach affects the social worker's topic control.

\section{Establishing social roles and constructing identities Asking the questions}

Institutional dialogue can be described as having role-structured, institutionalized, and omnirelevant asymmetries between participants in terms of such matters as differential distribution of knowledge, rights to knowledge, access to conversational resources, and to participation in the interaction' (Drew \& Heritage, 1992, p.49). The role difference between the social worker and the client in this study in terms of institutional role-differentiation is made obvious first through the task-orientedness of the interaction (Levinson, 1992), which imposes constraints on the topics that are being discussed. This becomes clear in the interview with the researcher, in which the social worker describes the agenda of the session: 'Today I have to look at that Social Welfare Service with her, about the Tax Service, and just look how she is doing'. Furthermore, elements such as efficiency and time pressure are circumstances that the participants need to deal with during institutional interactions. In this case, the social worker scheduled the appointments with clients and they usually last no longer than one hour.

A central means by which topics are controlled is by asking questions. As Sacks pointed out: 'As long as one is in the position of doing the question, then in part they have control of the conversation' (Sacks, 1992, p.49-55). Wang discerns three factors that turn questions into powerful means in institutional dialogue, of which two are relevant in the professional-client interaction we will present here: 'The first is that the notably unequal distribution of questions produces the unequal allocation of turn-taking. The second is that dominant questions control 
both local and global topics (...)' (Wang, 2006, p. 539). When analyzing the entire conversation between the social worker and the client, the distribution of direct questions ${ }^{3}$ is unequal: the social worker asked 99 direct questions, while the client only asked 9 direct questions. This results in the following distribution: $91.7 \%$ of all the questions were posed by the social worker, as opposed to $8.3 \%$ by the client.

Especially question sequences, which as we will see later occur regularly in the data, are stepwise ways of forming conversational topics and thus support the goal-oriented nature of institutional dialogue (Wang, 2006). It is not only through questions, but also through the way the social worker is dealing with other aspects of the conversation, such as unwanted topics and side sequences, that she is controlling the topics that are being discussed.

\section{A balancing act}

Drew and Heritage positioned social work-interactions in a non-formal setting and in a private context (the counselling room), where there is considerable space for negotiation and stylistic variation, in contrast to a formal setting like a courtroom, which is structured by formal procedures and takes place in a public context (Drew \& Heritage, 1992; Arminen, 2000). Drew and Heritage also argued that in these informal settings 'boundaries between institutional talk and ordinary conversation can appear permeable and uncertain' (1992, p.28). This characterization also holds for interactions in a Dutch social work context, which sometimes resemble a balancing act between institutional and mundane conversation (cf. Pithouse \& Atkinson, 1988). In the interviews the social workers accounted that they empathize with the clients to create safety and trust. But also a pragmatic and confronting attitude is used to mark the distance between the professional and the client. This balancing and drawing boundaries is part and parcel of the client-centred repertoire that social workers account when talking about their everyday practices (cf. van der Haar, 2007), as is illustrated by the following social worker's account: 'on the one

\footnotetext{
${ }^{3}$ Indirect questions were excluded from the counting, since we found in this case that such questions did not interfere with the interactional rules and did not signal power. Examples of such indirect questions were found when the client voiced possible criticism her fellow students had of her life, for instance about her young age when she married or about the fact that she was divorced. These types of questions served different interactional functions, but were not related to topic control in the way sequences of direct questions were.
} 
hand you need to provide the security of a friend, on the other hand you need to keep the distance of a professional caregiver'.

\section{Two identity constructions}

In the data, the client predominantly positions herself as a woman who is both afraid of what may happen in the future and ashamed of what happened in the past. Her fear mostly concerns the fact that her husband may try to come after her and hurt her again, but it is also about the insecurity of her future in the Netherlands. Next to being afraid, the client also expresses her feelings of shame about the fact that she ran away from her husband and is all alone now, which she describes as unacceptable to herself and her family. We will now discuss these two positionings in more detail.

\section{A fearful woman}

The topic of fear is introduced into the conversation by the client in response to the social worker's invitation to elaborate on her statement (line 90) that she 'cannot trust anybody'.

90 C: $\quad$ lk ken niemand vertrouwen.

91 MW: Ja.

92 C: En (.) ik bang altijd.

93 MW: Want, hoe bedoel je: 'lk kan niemand vertrouwen?'

94 C: Ja op school, mijn vriendinnen vragen: 'Woon je alleen?, met ouders?, met

95 jouw man?' Maar ik durf niet vertellen aan hun, omdat ik ben bang,

$96 \quad$ misschien zij zijn Afghaans.

97 MW: Ja.

98 C: En eh misschien hun kennen mijn man, Afghaanse mensen kennen

99 elkaar (.) mijn man oh, C, X ((noemt woonplaats)) 
90 C: I cannot trust anybody.

91 SW: Yes.

$92 \quad$ C: $\quad$ And (.) I afraid always.

93 SW: Because, what do you mean: 'I cannot trust anybody?'

94 C: Yes at school, my friends ask: 'Do you live alone?, with parents?, with

95 your husband?' But I dare not tell them, because I am afraid

96 maybe they are Afghan.

97 SW: Yes.

98 C: And erm maybe they know my husband, Afghan people know each other (.) my husband oh, $\mathrm{C}, \mathrm{X}$ ((names residence))

In this fragment, the client initiates the topic of fear and describes the extent of her fear (altijd, 'always'). She repeats this topic in line 95, and adds a reason to this topic in the rest of the conversation (lines 96 and 98-99). The social worker minimally responds by means of the affirmative particle ja ('yes') in lines 91 and 97, and by asking for explanation (line 93) by mirroring the client's formulation of line 90 . So the client is introducing and expressing her fear, independent of the social worker's guidance or questions.

This construction of the client as a fearful woman is explored later in the conversation by means of the discussion of what would happen if the client's husband found out where she lives. In this fragment, they are discussing how the client would feel if she had official permission to stay in the Netherlands. In line 292, she asserts that if she had such permission, she would not be so concerned if her husband knew where she lived.

292 C: Ja, daar, mijn man ook weet waar woon ik is niet erg voor mij.

293 MW: Ok, dus dat maakt jou dan een beetje minder bang

294 C: Ja, minder bang, nu ben ik helemaal bang voor alles, als hij weet

295 waar ik woon ik 
MW: $\quad M m m m$.

297 C: $\quad$ Misschien als hij komt bij mijn deur

298 MW: $\quad M m m m$.

299 C: $\quad$ Misschien ik ga dood

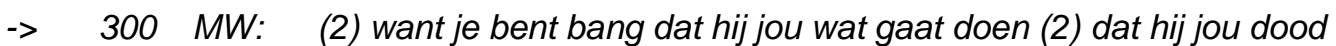

$301 \quad$ gaat maken $\mathrm{mm} \mathrm{C}$, ben je daar bang voor?

302 C: $\quad$ (3) Ook

303 MW: Hoe bedoel je dat? 'Ik ga dood', dat is wat je zegt hè?

304 C: $\quad$ Ik bedoel ik bang

305 MW: Zo bang

306 C: $\quad$ Ja, zoo bang en

307 MW: Ok

292 C: Yes, there, my husband knows also where I live, it not bad for me.

293 SW: Okay, so that makes you a little less afraid.

294 C: Yes, less afraid, now I am all afraid of everything, if he knows

$295 \quad$ where I live I

296 SW: $\quad M m m ~ m m$

297 C: $\quad$ Maybe if he comes to my door

298 SW: $\quad M m m ~ m m$

299 C: $\quad$ Maybe I will die

$\rightarrow \quad 300$ SW: $\quad$ (2) because you are afraid that he will do something to you (2), that he will

$301 \quad$ kill you $\mathrm{mm}, \mathrm{C}$, are you afraid of that?

302 C: $\quad$ (3) Also

303 SW: What do you mean? 'I will die', that is what you are saying, isn't it?

304 C: I mean I afraid.

305 SW: So afraid.

306 C: $\quad$ Yes, soo afraid and 


\section{SW: Okay}

In line 293 the social worker reintroduces the topic of fear, which is quickly picked up by the client and then emphasized by way of the extreme case formulations helemaal ('all') and alles ('everything') (Pomerantz, 1986) and the threefold repetition of the emphasized way of talking. Furthermore, in line 299, the client suggests that she will die 'if he comes to her door'. In the next turn, the social worker formulates her interpretation of the reason for this extreme consequence of the husband's coming to the client's door, namely that he will kill her, and in so doing fixes its meaning. She formulates her reasoning quite factually and then asks for the client's affirmation of her interpretation by means of an open question. The client's answer however is only a partial affirmation of her interpretation (we will come back to this point in the discussion of fragment 6). The social worker thus questions her further in line 303 and again provides her own interpretation of the reason of the client's fear. In the final turn, the client reasserts her feelings of fear without directly confirming that her fears include her husband killing her. The social worker first upgrades this expression of fear in line 305 by the addition of $z o$ ('so'). The client affirms this upgraded expression, but again avoids specific confirmation of the fear she will be killed by adding the conjunction en ('and'). At this point, the social worker further explores the client's emotion of fear, leaving aside the discussion of the possibility that her former husband would kill her. This fear of being killed is not new and has already been discussed in the intake report written by the social worker, which states that the client 'is afraid she will have to return to Afghanistan and that she will be killed there.' In this fragment, we saw both in lines 300 and 305 the active role of the social worker in constructing the identity of the fearful woman.

\section{A shameful woman}

The introduction of the topic of shame is quite different from the way the topic of fear was introduced, even though both topics are introduced right after one another in the conversation. 
114 MW: Ja (.) want is het zo C van dat díe meisjes eh ook alleen zijn in

$115 \quad$ Nederland of hebben die familie, zeg maar.

116 C: $\quad$ Nee, familie

117 MW: Familie in Nederland?

-> 118 C: Ja, ik schaam mij echt, iedereen komt bijvoorbeeld moeder,

$119 \quad$ vader hun komen ophalen op school

120 MW: $M m m$.

121 C: En met zijn broer op school zitten. En ik helemaal alleen.

122 MW: $M m m$.

123 C: Daarom ik wil ook niet contact met hun, om als je hen willen

124 met mij ouders, kennissen

125 MW: $M m m$.

126 C: En, komen bij ons, wij gaan daar.

-> $127 \mathrm{MW}: \quad \mathrm{Mmm}$, en jij zegt ook iets he $C$, van dat je je dan schaamt hè?

128 C: Ja.

129 MW: Want hoe bedoel je? Dat jij (.) Waar schaam je je dan over?

130 C: Ja, schaam mij ook, omdat ik helemaal alleen en hun gaan lachen

131 voor mij zeggen: 'Oh zij is alleen en zij heeft niemand.'

$132 \mathrm{MW}: \mathrm{Mm} \mathrm{mm}$.

133 C: $\quad$ Misschien zijn ouders slecht? (.) veel meer dingen.

114 SW: Yes (.) because it is like that, C, of that those girls erm are also alone in

115 the Netherlands or do they have family, let's say.

116 C: No, family

117 SW: Family in the Netherlands?

-> 118 C: Yes, I am really ashamed, everybody comes for example mother, 119 father come to pick them up at school.

120 SW: Mmm. 
121 C: And being at school with his brother. And I all alone.

122 SW: Mmm.

123 C: That is why I also do not want contact with them, to if you them want ${ }^{4}$

$124 \quad$ with my parents, friends

125 SW: Mmm.

126 C: And, come to us, we go there.

-> 127 SW: Mmm, and you also say something hey C, of that you are ashamed, hey?

128 C: Yes.

129 SW: Because what do you mean? That you (.) What are you ashamed of then?

130 C: Yes, I am also ashamed, because I am all alone and they start laughing

131 for me say: 'Oh, she is alone and she has nobody.'

132 SW: $\quad \mathrm{Mm} \mathrm{mm}$.

133 C: Maybe parents are bad? (.) lots more things.

The differences between the reactions of the social worker in this fragment and fragment 1 are noticeable. First, the social worker does not pick up the subject of shame until nine lines after the client first initiated it, in line 118. The social worker follows up on the topic in line 127, and then reformulates her question in line 129, after a minimal affirmative response in line 128. Her reformulation suggests that the social worker does not understand the link the client has established between the absence of family and shame in the previous turns. Second, the rest of the turns of the social worker consist of a single continuer $(\mathrm{mmm})$, which is repeated in lines 120 , 122, 125 and 132. This response is less affirmative than the social worker's affirmation of the client's identity construction of being fearful. The response in this fragment simply encourages the client to keep on talking without further positive affirmation. The continuer in line 125 is noteworthy, since the client's sentence in lines 123-124 goes totally wrong and is unintelligible. Instead of asking for repair, the social worker keeps on responding minimally. Both the questions and the minimal responses of the social worker in this fragment show that the identity

\footnotetext{
${ }^{4}$ This sentence is a literal translation of the Dutch original, which is unintelligible.
} 
construction of a shameful woman is less useful to work on in terms of a social work intervention to her than that of the fearful woman. This may be because the client frames this identity construction of the shameful woman as rooted in her cultural background. Throughout the conversation, the client repeatedly invokes what is acceptable and unacceptable in Afghan culture to explain her situation. In the next fragment, the social worker introduces the hypothetical situation of when the client would tell other people about her position of being a woman who left her husband. The client replies by explaining that a woman will in any case be blamed for the failure of a marriage and introduces 'our culture' as a resource to strengthen her argument (cf. Anis, 2005).

155 MW: Mmm. (.) Want zou het ook zo kunnen zijn, $C$ dat, als jij het vertelt hè? Dat zij 156 zeggen van: 'Oh, wat erg, voor jou?' (.) Dat zij, dat zij niet jou de schuld geven hè.

157 C: Zij zullen mij de schuld geven en niet mijn ouders, niet mijn man.

$158 \mathrm{MW}: \mathrm{Mm}$.

159 C: Bij onze cultuur is eh, als je meisje getrouwd=

$160 M W:$

$$
=M m m m .=
$$

$161 C$ :

=zij moet $A L T I J D$ blijven,

maakt niet uit als je haar man slecht of niet slecht, =

$163 M W$ :

$$
=M m m m .=
$$

164 C: =moet zij blijven, moet niet gescheiden.=

$165 M W$ :

$$
=M m .=
$$

$166 C$

= en zij gaat, zij is gescheiden,

168 MW:

$=M m .=$

169 C: =Bij haar man. 
171 C: Onze culturur is zo.

172 MW: Ja. Maar jij hebt mij ook wel es verteld hè $C$, dat sóms het zo is dat het

173 eh dat dat echt niet mág hè maar dat andere mensen ook wel es denken

174 dat als man écht héél slécht is

175 C: $\quad M m m$.

176 MW: voor vrouw

177 C: Ja

178 MW: dan is eh man óók níet góed hè (.) want de man die mag niet slaan of die man die mag niet al die dingen doen die hij bij jou heeft gedaan hè.

155 SW: Mmm. (.) Because could it also be, C, that if you tell it eh? That they say like:

156 'Oh, how awful, for you?' (.) That they, that they do not blame you right?

157 C: They will blame me and not my parents, not my husband.

158 SW: Mm

159 C: In our culture is er, if a girl married=

160 SW:

$=\mathrm{Mm} \mathrm{mm} .=$

162 C:

= she ALWAYS has to stay,

163 does not matter if your if her husband is bad or not bad,=

164 SW:

$=\mathrm{Mm} \mathrm{mm} .=$

164 C: = must she stay, must not divorce.=

165 SW: $=M m .=$

166 C:

$=$ and she goes, she is divorced,

167 them go think: 'Oh, erm she is erm maybe not good wife', was=

168 SW:

$=\mathrm{Mm}=$

169 C: =With her husband.

170 SW: $\quad \mathrm{Mm} \mathrm{mm}$. 
171 C: Our culture is like that.

172 SW: Yes. But you have once told me right C, that sometimes it is like that that it

173 uh that it really is not allowed, hey, but that other people also think every

174 now and then that if man is really very bad

175 C: $\quad M m ~ m m$

176 SW: for wife

177 C: $\quad$ Yes

178 SW: then man is uh also not good hey (.) because the man he cannot hit or that 179 man he cannot do all those things that he did to you hey.

In the fragment above, the social worker provides an alternative for the reaction the client anticipates if she tells anybody of her problems. Both in lines 155 and 156 the social worker offers an alternative, more sympathetic reaction, both by mimicking the actual words in the direct quote in line 155-156, and the rephrase in line 156. The client's reaction to this suggestion is direct and matter of fact, using the simple future tense (ze zullen mij de schuld geven, 'they will blame me'). Her response is made emphatic, by the contrast of mij ('me') versus the others (mijn ouders, mijn man, 'my parents', 'my husband'), which are both related to her through the repeated use of the possessive pronoun mijn ('my'), but also contrasted with her by means of the repetition of the negative particle niet ('not'). In line 159 the client elaborates on this argument with minimal responses by the social worker. The client goes on to invoke culture as an 'explanatory factor' (Bulcaen \& Blommaert, 1999) in quite an emphatic way, as is shown through the stressed way of expressing the word altijd ('always'), the repetition of the modally marked moet zij blijven ('she has to stay') and the voicing of what people would say if the wife leaves her husband by means of direct speech, thus mimicking another's voice, which is a typical performance feature (Baynham, 2006). At one point in her monologue, the client also mitigates her statements by means of the hedge misschien ('maybe') on line 167 (we will come back to this point in the Conclusions). She closes her argumentation by factually concluding that that is the way it is in 'our culture', with which she explicitly associates herself through the use of the first person plural possessive onze 
('our'), thus emphasizing her in-group identity. In this section of the fragment, the client's position in the conversation is dominant since she has unique access to this type of knowledge. Then, the social worker formulates her alternative again from line 172 to 180 . The social worker here takes over some of the features of the client's language, which are typical of a non-native speaker: (1) she also uses the words 'good' and 'bad' which refer to very basic language in a way you do not expect from a native speaker of Dutch and (2) she leaves out the definite particle three times (two times before 'man' (lines 174 and 178) and once before wife (line 176)), which is grammatically incorrect in Dutch. We may interpret this language act as a very literal way of linking up where the client stands', which also becomes clear from the hesitant way in which she formulates her alternative, as the hedges (lines 172 - 174: 'sometimes' and 'every now and then') underline. The social worker still does not convince the client that not all people will judge her as 'not good wife' (line 167) with the same argument of how 'in her culture' this kind of behaviour is unacceptable for a woman, as is shown in the following fragment:

(5)

\author{
182 C: $\quad$ Maar eh bij ons mag (.) mannen wat doen, vrouwen moeten \\ 183 MW: mogen niks zeggen \\ 184 C: niks zeggen
}

182 C: But uh with us is allowed (.) men do something, women have to

183 SW: are not allowed to say anything

184 C: say nothing

This fragment shows how this 'cultural' explanation is formulated by the client as a difference in modality: men are related to the verb mogen ('to be allowed to'), while women are the subject of the verb moeten ('to have to'). The social worker narrows this general distinction in her completion in line 183 as 'not being allowed to say anything', which is then confirmed by the client's repetition in line 184. 
Fragment 4 deviates from fragment 3 because in the latter, the social worker guided the conversation more explicitly and used the continuers $(\mathrm{mmm})$ to stimulate the client to keep on talking while the client is complying with the social worker's suggestions and giving affirmative responses to her questions. In fragment 4 , however, the client is almost presenting a monologue and thus, she is explicitly taking the floor and controlling the topic. The social worker's continuers are latched to the client's turns and this lack of pauses shows that they are only supporting the client's flood of words, instead of stimulating the client to talk. The client thus positions herself as knowledgeable about 'our culture' and her vantage point within it contextualizes her identity construction as a shameful woman.

Furthermore, the client's frame of reference is explanatory for the partial affirmation (ook, 'also' in line 302) in fragment 2 above. The client did not overtly disagree with the social worker's reasoning, implying at least partial agreement. However, much later in the conversation, the client initiates this topic again and provides a totally different explanation of why she could die.

(6)

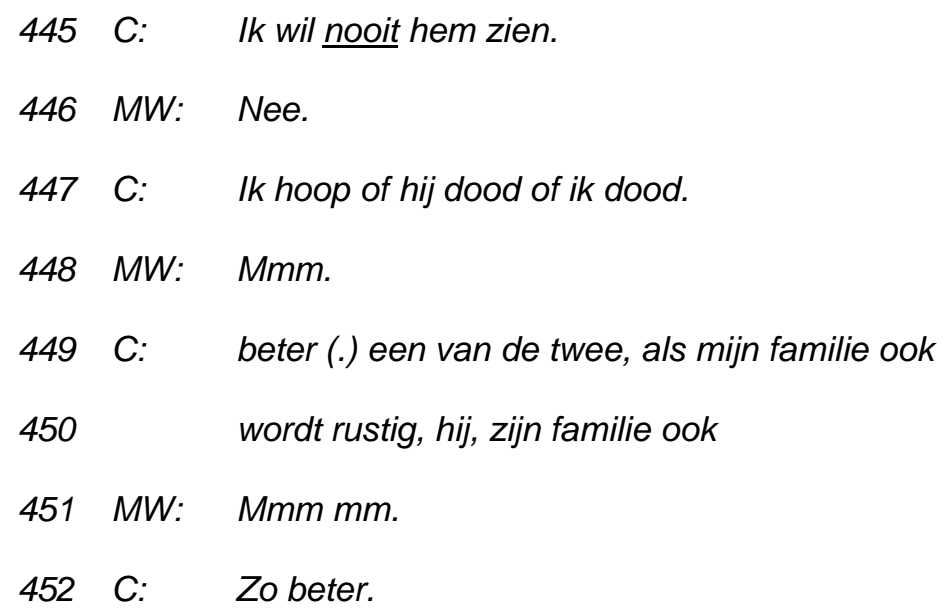


449 C: $\quad$ better (.) either one of the two, if my family also

450 becomes quiet, he, his family too

451 SW: $\quad M m m m$ m.

452 C: Better like that.

The client introduces the topic of not wanting to see her husband again in line 445 . This negative assertion is corroborated by the social worker in line 446 (nee, 'no'). Then the client introduces the topic of dying again, but this time she presents it as a dichotomy between him or her (line 447), which is further explored in line 449 in which the client inserts the families in her argument as well. Finally, she closes the topic in line 452 by evaluating her statements herself, which is quite atypical of the client in comparison with the rest of the conversation. The social worker takes on a relatively passive position again by reacting only with the continuer $\mathrm{mmm}$. The client takes on a much more active role in the conversation, by introducing and evaluating topics herself, turns typically dominated by the social worker in the rest of the conversation. She constructs her identity of a shameful woman when she explains her position from a cultural point of view, without agreement or support from the social worker.

\section{Shifting between the client's perspective and the social worker's goals}

In the fragments discussed so far, the social worker, as a representative of her organization, had sort of a double role. First, she is a guide or agenda setter, since she is mostly initiating the topics that are being discussed, and which are being guided by means of the questions she is asking. Second, she is also quite a passive listener who allows the client to hold the floor and construct the identity of a shameful woman, as we saw in the fragments above. That is, although the 'discourse ecology' (Agar, 1985) of this conversation is guiding the social worker towards a certain task and a specific goal she wants to attain during the talk with her client, she also lets the client voice her own opinions and construct her own meanings, particularly those grounded in claims about the way the client relates to her Afghan background. 
This sometimes leads to long sequences of mitigated topic negotiations, in which the social worker is shifting between following her agenda and letting the client control the topic. It is especially in these sequences, that we see how the client presents herself and how she makes sense of her situation. In the fragment below, the social worker is having a specific agenda with her question in line 318 , namely that she wants the client to know that when her former husband would visit her she knows that she has to call the police and report the event (lines 374-380, omitted here). Yet, the client understands this quite differently.

(7)

311 MW: Dus dat lijkt je HEEL $\underline{\text { eng }}$ als ie komt

312 C: HEEL eng, 's avonds toen wil ik naar bed toe

313 MW: Jaa.

314 C: $\quad$ eh (.) moet ik eh heel veel eh dingen uit onze boek lezen voor

315 beschermen van mijzelf

316 MW: $\quad M m m m$.

317 C: dan pas naar bed, omdat ik ben erg bang misschien hij doet iets [mij

-> $318 \mathrm{MW}:$ [want

319 in dat boek staat wat je moet doen?

320 C: $\quad$ Ehm, ja gewoon paar eh zingen, wij moeten die liedje, wij moeten zingen

321 MW: $\quad$ Mmm mm.

311 SW: So that seems VERY scary to you if he comes

312 C: VERY scary, at night then I want to go to bed

313 SW: Ye-es.

314 C: $\quad$ erm (.) I have to erm read a whole lot of erm things from our book for

$315 \quad$ protecting of myself

316 SW: $\mathrm{Mmm} \mathrm{mm}$.

317 C: only then to bed, because I am very afraid maybe he does something [me 
319 in that book it says what you have to do?

320 C: Erm, yes, just a couple erm singing, we have to that song, we have to sing

321 SW: $\quad M m m ~ m m$.

In this fragment, the social worker is introducing the topic of fear again in line 311 , which she does in an emphatic way. The client takes over this emphatic expression of fear, and starts telling the social worker what she does before going to bed. The social worker encourages the client's response to the social worker's topic reintroduction by the affirmative particle jaa ('ye-es'), which is also pronounced in an emphatic way. And so the client starts telling her that she reads things from onze book ('our book'), in this case meaning the Koran (made explicit in line 330):

(8)

322 C: en dan gaan slapen voor beschermen goed

$323 \mathrm{MW}: \mathrm{Mmm}$

324 C: $\quad$ Wij hebben geloof daar

325 MW: Jaaa, een soort slaapliedje (2)

326 die je altijd zíngt voor dat je gaat slapen,

327 of kan je hem de hele dag zingen?

328 C: Nee nee nee nee nee, soms, als je wil met God praten

329 MW: Ja

-> 330 C: $\quad$ En jij gaat die zingen van Qur'an

322 C: and then go sleeping for protecting good

323 SW: $\mathrm{Mmm}$

324 C: We have religion there

325 SW: Ye-es, some kind of lullaby (2)

326 that you can always sing before you go to sleep, 
328 C: No no no no no, sometimes, if you want to talk to God

329 SW: Yes

$\rightarrow \quad 330$ C: $\quad$ And you go sing of Qur'an

The first person plural possessive pronoun onze ('our') in line 314 is indicative of the client's affiliation, which is to be understood as within a Muslim culture in Afghanistan. She also marks her identity with a spatial reference by saying 'we have religion there' (line 324) presumably referring to her country of origin (cf. Blommaert, 2005). So in fragment 7 , the social worker misinterprets the reference to onze book ('our book', line 314) and thinks that it is some sort of practical guide of what the client can do, as is shown in the question in line 318 . The social worker's misunderstanding is based on the misinterpretation of the possessive pronoun onze, probably as an inclusive (in this case as some kind of manual provided by the social worker) instead of as an exclusive pronoun (in this case as the religious book of Muslims, the Koran). The client interprets the social worker's practical question and its modality from a different perspective. In line 320, she responds affirmatively (ja, 'yes') and also takes over the social worker's modality (moeten, 'have to'). Again, she uses the exclusive we-form, categorizing herself within the group of Muslims (cf. Leudar et al, 2004).

After this exchange, the social worker listens to the client's explanation of reciting and then moves talk back to the topic introduced by the question in line 318 (want in dat boek staat wat je moet doen?, 'because in that book it says what you have to do?'). So in line 363 , the social worker reintroduces the topic of what the client would do in case her ex-husband comes to her door.

(9)

361 MW: Dat dat zo kan dat je daar ook een beetje rust bij vindt hè

362 C: $\quad(\quad)$

-> $363 \mathrm{MW}: \quad \mathrm{Ja}$, is heel goed (3) Ja, want weet je ook wat je wat jij zou doehoen C, 
365 C: $\quad$ (3) Nee, ik weet niet.

366 MW: Wat zou je doen?

367 C: $\quad$ (3) Ik weet niet wat moet ik doen (3)

368 MW: Bedenk's (2) Want het is wel belangrijk dat je dat weet hè?!

369 C: Jaa, ehm, ik net tegen jou, als hij ik weet hij bij mijn deur, ik ga flauwvallen

$370 \mathrm{MW}: \quad$ Van angst?

371 C: $\underline{\text { Ja }}$

361 SW: That that is possible like that that you find a little bit of peace in that, hey

362 C: ()

-> 363 SW: Yes, is very good (3) Yes, because do you also know what you what you

364 would dohoe ${ }^{5} \mathrm{C}$, if he comes to your house, do you know then what you have to do?

365 C: (3) No, I don't know.

366 SW: What would you do?

367 C: (3) I don't know what I have to do (3)

368 SW: Think about it (2) Because it is indeed important that you know that hey?!

369 C: Ye-es, erm, I just to you, if he I know he at my door, I will faint

370 SW: Of fear?

371 C: $\quad \underline{\text { Yes }}$

We see in line 361 and also emphatically in line 363 that the social worker is positively evaluating the prayer song as a practical way to manage the stressful situation the client faces. Then after a three second pause in line 363 she reintroduces her practical topic of how the client would react. The social worker stresses the practical nature of her question through the very emphatic pronunciation of doehoen ('dohoe'), the reformulation on line 363 wat je wat jij ('what

\footnotetext{
${ }^{5}$ The orthography 'dohoe' mirrors the social worker's emphatic pronunciation of the verb 'to do'.
} 
you, what you') in which the first je ('you') is the unstressed, and the second jij ('you') the stressed form of the second person in Dutch, and the use of the modal verb moeten ('have to') on line 364, which the social worker used in her initial question in line 318 as well. In lines 365 and following, the social worker gives the client a lot of time to answer the question (cf. pauses on lines 365, 367 and 368). She also stresses the importance of the subject (line 368) and she keeps on reformulating her questions until she gets an adequate answer from the client. The amount of pauses, the emphasis and the reformulation all show that in this fragment, it is up to the social worker to decide at which point this topic is dealt with sufficiently and thus this is a moment of particularly clear power imbalance. The client's answer finally comes in line 369 (ik ga flauwvallen, 'I will faint'), which is not a preferred response for the social worker as is shown in the follow-up of this fragment, but which the social worker again responds to with understanding, as we see in her reaction in line 370 , which is actually a repetition of the initial topic that the social worker introduced in line 311 (Dus dat lijkt je HEEL eng als ie komt, 'So that seems VERY scary to you if he comes'). So they are back to where they started, which is not a very successful interaction when you look at it from a purely goal- or task-oriented point of view. The social worker's reaction in line 370 is not negative, which it would be in a purely goal-oriented context, since a bit further in the conversation she points at practical tools to protect herself, e.g. phoning the police.

So in the fragments 7 and 9, it became clear through the lack of success in achieving the social worker's goals, that the social worker is making efforts to leave space for the client's personal meaning-making and that she is acknowledging the client's way of positioning herself within and relating to her cultural background.

\section{Conclusions}

In this interaction, we studied the construction of two client identities, namely that of the fearful woman and of the shameful woman. The former identity is discerned, stimulated and coconstructed by the social worker, possibly because it relates to the dominant cultural frame of liberal morality in the Netherlands, but also to the Dutch state perspective on social work as part 
of public policy which provides social workers with the task to stimulate the self-reliance of its citizens. Yet, more practical matters are discussed as well. The topic of fear allows the social worker to introduce one of the practical issues on her institutional agenda, namely discussing the client's potential reactions to the hypothetical situation of an unwanted visit of her ex-husband. In the entire conversation, this subject of anxiety is brought up numerous times, both by the social worker and the client.

The other identity construction, namely that of the shameful woman, is not discussed to such a large extent. The social worker has no practical solution to offer, so the topic is dropped and does not recur. The lack of practical solutions, however, is not the only reason the topic is dropped, since the social worker allows room for discussion of psychosocial problems and in this case for the client's expression of her feelings of shame. More importantly, the client's identification with shame is not productive - in institutional terms - since the social worker intends to activate the client and to encourage her to break out of her isolated position. As a result, the topic of shame is again reformulated by the social worker when she offers alternatives to the client in order to prevent shame from stopping the client having contact with other people.

Another reason for the limited discussion of this identity construction can be found in the link to the client's cultural background, which is introduced by the client herself. These references to the Afghan context and to Islam function as explanatory factors in her account of the situation (see also Bulcaen \& Blommaert, 1999). They are however used by the client in one situation as including and in another situation as excluding her from this cultural context. The client strongly positions herself within the Afghan background and categorizes herself as part of the Muslimcommunity (e.g. 8). However, this categorization is problematic, since her actions resulted in the disapproval of the Afghan community, which she says excludes her for that matter (e.g. 4). Furthermore, she hardly has any contact with this background, since she was not in touch with her family at the time of the conversation and she avoided meeting Afghan people (e.g. 1) because she feared their disapproval, and this made her self-categorization even more problematic. 
In general, the social worker has a dominant position in this conversation. That is, the social worker controls the topics and the client usually consents with the social worker's questions or suggestions. This pattern is interrupted when the client positions herself within a cultural and religious context and states that position in ways the social worker cannot dispute. In these cases, the client takes the floor and initiates, discusses, evaluates and closes the topics. Moreover, she explicitly disagrees with the social worker (e.g. 4, when discussing the question which of the two partners would be blamed for the failed marriage). From an interactional perspective, then, the client holds the dominant position when discussing her cultural background. In these moments, the social worker both leaves room for the client's opinions and lets her explain the cultural context relevant to her identity construction and to the actual circumstances she lives in, but also maintains topic control, as we saw in some other fragments (e.g. 7).

This case gives a good example of how "contact with 'the other" (De Fina, 2006, p.251) strongly influences the way identities are performed in a particular interaction. By using a performance-approach to identity (Baynham, 2006; Blommaert, 2005; De Fina, 2006), we demonstrated how the diverging interpretations of client identity and the reactions of the social worker on them reveal the complex relationship between social work goals and the client's perspective on the one hand, and the client's own ambiguous positioning towards her cultural and religious background on the other hand. Both were shown in the discussion of fragment 4 , in which the client emphatically positions herself within 'our culture'. By doing so, she is affiliating with the group she says she is excluded from as a result of her behavior as a wife, while the client's hedge 'maybe' left a tiny opening for accepting alternative explanations offered by the social worker speaking from a Dutch background and the social work goal to empower its clients (Struijs \& Brinkman, 1996). Actually, both the contrastive nature of the interaction in e.g. 4, in which the client 'position[s] [her] conversational partner as 'other" (Baynham, 2006, p.395) and the hedge that leaves open the possibility of alternative explanations, are emblematic of her identities that shift in and out of the client's cultural context. This problematic affiliation of the client with her Afghan background and the particular implications of this for her identity 
constructions and the way these are negotiated in the interaction, illustrate the necessity to study each intercultural interaction as a unique encounter. As Verschueren (2008, p.24) observed, 'an intercultural context is not to be equated with the sum of two different contexts, but essentially the creation of a new one.' The careful negotiation and co-construction of identities in this case illustrated this point.

Furthermore, the analysis of this interaction demonstrated the dynamics of institutional and culturally framed identities as social and situated constructions of meaning. Also, this interaction showed that power is not ascribed to the social worker merely, in spite of the asymmetrical distribution of questions, which is an example of the social worker performing a dominant role. Yet, the Afghan woman's performance of client identity indicates her dominance on the part of explaining her individual positioning towards her cultural background. This 'unique' sense making of the client's own socio-cultural context strengthens her position in the interaction and it gives the client an argument that is irrefutable by 'outsiders' like the social worker. This explains the fragments of reversed conversational dominance that are found in the data under study. To conclude, we would argue that these fragments reveal the professional's 'balancing act' of practicing a client-centred approach and at the same time performing focused social work interventions as it is talked into being on a day-to-day basis.

\section{References}

Androutsopoulos, J. \& Georgakopoulou, A. (2003). Discourse constructions of youth identities: Introduction. In J.K. Androutsopoulos \& A. Georgakopoulou (Eds.), Discourse constructions of youth identities (pp.1-25). Amsterdam: John Benjamins.

Anis, M. (2005). Talking about culture in social work encounters: immigrant families and child welfare in Finland. European Journal of Social Work, 8 (1), 3-19.

Agar, M. (1985). Questions and the exercise of power. Text, 5(3), 147-168.

Arminen, I. (2000). On the context sensitivity of institutional interaction. Discourse \& Society, 11 (4), 435-458. 
Baynham, M. (2006). Performing self, narrative and commuity in Moroccan narratives of migration and settlement. In A. De Fina, D. Schiffrin \& M. Bamberg (Eds), Discourse and Identity, Studies in Interactional Sociolinguistics 23 (pp. 376-397). Cambridge: Cambridge University Press.

Baumann, G. (1999). The multicultural riddle. Rethinking national, ethnic and religious identities. New York: Routledge.

Bulcaen, C. \& J. Blommaert, J. (1997). Eindrapport VFIK project 307, Begeleiding van migrantenvrouwen en meisjes in centra voor residentieel welzijnswerk. Wilrijk: IPrA Research Center.

Bulcaen, C. \& Blommaert, J. (1999). De constructie van 'klassieke gevallen'. Case management in de interculturele hulpverlening. In F. Glastra (Ed.), Organisaties en diversiteit. Naar een contextuele benadering van intercultureel management (pp. 139-158). Utrecht: Lemma.

Blommaert, J. (2005). Discourse. A critical introduction. Cambridge: Cambridge University Press.

De Boer, N. \& Duyvendak, J.W. (2004). 'Welzijn'. In H. Dijstelbloem, P.L. Meurs \& E.K. Schrijvers (Eds.), Maatschappelijke dienstverlening. Een onderzoek naar vijf sectoren (pp. 17-63). Amsterdam: Amsterdam University Press.

De Fina, A. (2003). Identity in narrative, A study of immigrant discourse. Amsterdam / Philadelphia: John Benjamins Publishing Company.

De Fina, A. (2006). Group identity, narrative and self-presentations. In A. De Fina, D. Schiffrin \& M. Bamberg (Eds), Discourse and Identity, Studies in Interactional Sociolinguistics 23 (pp. 351-375). Cambridge: Cambridge University Press.

Drew, P. \& Heritage, J. (1992). Analyzing talk at work: an introduction. In P. Drew \& J. Heritage (Eds.), Talk at work - Interaction in institutional settings (Studies in Interactional Sociolinguistics 8) (pp. 3-65). Cambridge: Cambridge University Press.

Dutch Welfare Law (Welzijnswet) (1994). Staatsblad 1994, 447.

Gastelaars, M. \& van der Haar, M. (2007). Facing culture: the (de)legitimation of social work. International Journal of Sociology and Social Policy, 27 (11/12), 447-459. 
Hall, C., Slembrouck, S. \& Sarangi, S. (2006). Language practices in social work. Categorisation and accountability in child welfare. London: Routledge.

Hall, S. (2000). Who needs 'identity'? In P. du Gay, J. Evans \& P. Redman (Eds.), Identity: a reader (pp. 15-30). London: Sage.

Leudar, I., Marsland, V. \& Nekvapil, J. (2004). On membership categorization: 'us', 'them' and 'doing violence' in political discourse. Discourse \& Society, 15 (2-3), 243-266.

Levinson, S.C. (1992). Activity types and language. In P. Drew \& J. Heritage (Eds.), Talk at work: interaction in institutional settings (Studies in Interactional Sociolinguistics 8) (pp. 66-100). Cambridge: Cambridge University Press.

Pithouse, A. \& Atkinson, P. (1988). Telling the case. Occupational narrative in a social work office. In Coupland, N. (Ed.) Styles of discourse (pp. 183-200). London: Croom Helm.

Pomerantz, A. (1986). Extreme case formulations: a way of legitimizing claims. Human Studies, 9, 219-29.

Sacks, H. (1992). Lectures on conversation, volume 1. Oxford UK / Cambridge USA: Blackwell.

Stenson, K. (1993). Social work discourse and the social work interview. Economy and society, $22(1), 42-76$.

Struijs, A. \& Brinkman, F. (1996). Botsende waarden: ethische en etnische kwesties in de hulpverlening. Utrecht: NIZW.

Van der Haar, M. (2007). Ma(r)king differences in Dutch social work. Professional discourse and ways of relating to clients in context. Amsterdam: Dutch University Press.

Verschueren, J. (2008). Intercultural Communication and the Challenges of Migration. Language and intercultural communication, 8 (1), 21-35.

Wang, J. (2006). Questions and the exercise of power. Discourse \& Society, 17 (4), 529-548.

\section{Biographical note:}

Dorien Van De Mieroop received her PhD in Linguistics in 2005 from the University of Antwerp. In her research she focuses on the construction of identity, both within institutional contexts and in narratives of personal experience. She published a number of articles on this topic, among others 
in Discourse \& Society, Journal of Pragmatics and Discourse Studies. She is currently working at Lessius/KULeuven in Antwerp, where she teaches Dutch linguistics and language proficiency.

Marleen van der Haar is a Cultural Anthropologist and currently works as a postdoctoral researcher at VU University in Amsterdam. She received her PhD in 2007 from the Utrecht School of Governance, Utrecht University. In her dissertation on the ways Dutch social workers relate to their culturally diverse clientele she combined an ethnographic-oriented and a discourseanalytical approach.

Author affiliations

Dr. Dorien Van De Mieroop

Lessius / KULeuven

Department of Applied Language Studies

Sint-Andriesstraat 2

B - 2000 Antwerpen

Belgium

dorien.vandemieroop@lessius.eu

++ 3232060491

Dr. Marleen van der Haar

VU University

Department of Culture, Organization and Management

De Boelelaan 1081c

1081 HV Amsterdam

The Netherlands

m.van.der.haar@fsw.vu.nl

++ 31205986740 
